University of Nebraska - Lincoln

DigitalCommons@University of Nebraska - Lincoln

USDA Forest Service / UNL Faculty Publications U.S. Department of Agriculture: Forest Service -National Agroforestry Center

2012

\title{
Effect of Archer Density on Elk Pregnancy Rates and Conception Dates
}

Gregory A. Davidson

Oregon Department of Fish and Wildlife, greg.a.davidson@state.or.us

Bruce K. Johnson

Oregon Department of Fish and Wildlife

James H. Noyes

Oregon Department of Fish and Wildlife

Brian L. Dick

USDA Forest Service, bldick@fs.fed.us

Michael J. Wisdom

USDA Forest Service, mwisdom@fs.fed.us

Follow this and additional works at: https://digitalcommons.unl.edu/usdafsfacpub

Davidson, Gregory A.; Johnson, Bruce K.; Noyes, James H.; Dick, Brian L.; and Wisdom, Michael J., "Effect of Archer Density on Elk Pregnancy Rates and Conception Dates" (2012). USDA Forest Service / UNL Faculty Publications. 224.

https://digitalcommons.unl.edu/usdafsfacpub/224

This Article is brought to you for free and open access by the U.S. Department of Agriculture: Forest Service -National Agroforestry Center at DigitalCommons@University of Nebraska - Lincoln. It has been accepted for inclusion in USDA Forest Service / UNL Faculty Publications by an authorized administrator of DigitalCommons@University of Nebraska - Lincoln. 


\title{
Effect of Archer Density on Elk Pregnancy Rates and Conception Dates
}

\author{
GREGORY A. DAVIDSON, ${ }^{1}$ Oregon Department of Fish and Wildlife, 1401 Gekeler Lane, La Grande, OR 97850, USA \\ BRUCE K. JOHNSON, Oregon Department of Fish and Wildlife, 1401 Gekeler Lane, La Grande, OR 97850, USA \\ JAMES H. NOYES, Oregon Department of Fish and Wildife, 1401 Gekeler Lane, La Grande, OR 97850, USA \\ BRIAN L. DICK, USDA Forest Service, Pacific Northwest Research Station, La Grande, OR 97850, USA \\ MICHAEL J. WISDOM, USDA Forest Service, Pacific Northwest Research Station, La Grande, OR 97850, USA
}

\begin{abstract}
Archery hunting in Oregon has increased dramatically over the past 2 decades. At the same time, spring juvenile to adult female ratios of Rocky Mountain elk (Cervus elaphus) have been declining. This has raised concern that archery seasons may be disrupting elk breeding and contributing to the decline in recruitment. Two mechanisms could contribute to reduced juvenile:female ratios: 1) reduced pregnancy rates, and 2) delayed conception dates because of human disturbance during the rut. We varied the number of archery hunters at the Starkey Experimental Forest and Range over 13 years to evaluate effects of archer density on reproduction of elk. Archer densities were maintained at high densities during 4 years $\left(\bar{x}=1.09\right.$ tags sold $\left./ \mathrm{km}^{2}\right)$, low densities during 3 years $\left(\bar{x}=0.53\right.$ tags sold $\left./ \mathrm{km}^{2}\right)$, and no archers during 6 years. We determined pregnancy status, age, kidney fat index (KFI), lactation status, and fetus conception dates for 622 female elk harvested in December. We found pregnancy rate differences of 0.105, 0.080, and 0.021 between high and no archer density years $(P=0.004)$, high and low archer density years $(P=0.054)$, and low and no archer density years $(P=0.616)$, respectively. Conception dates were 4 days later for high archer density compared to low archer density $(P=0.006)$, but did not differ between high and no archer years ( 2 days; $P=0.136)$ or between low and no archer years $(2$ days; $P=0.108)$. We compared generalized linear model estimates of pregnancy rates and determined pregnancy rates for $28 \%$ of the lactating female elk to be affected by high archer density, whereas archer densities had no significant affect on pregnancy rate estimates for non-lactating females. We found no difference in conception dates among archer densities when comparing model estimates. Our results suggest that archer density and its interaction with nutritional condition of elk influence pregnancy rates of lactating females with low KFI levels; however, the effect of archer density alone does not explain the magnitude of decline in juvenile to female ratios observed in Oregon. (c) 2012 The Wildlife Society.
\end{abstract}

KEY WORDS archery, Cervus elaphus, conception date, elk, hunter density, hunting, nutritional condition, Oregon, pregnancy rate.

Spring recruitment estimates for juvenile elk (Cervus elaphus; juvenile:female ratios) declined from $>50: 100$ in the 1960s to current estimates of $<14: 100$ in some management units of northeast Oregon (Oregon Department of Fish and Wildlife 2003). Concurrently, elk populations declined in these same management units (Oregon Department of Fish and Wildlife 2010). Declining populations have also been documented in some areas of Washington (Washington Department of Fish and Wildlife 2009), and reduced productivity and populations have occurred in Idaho (White et al. 2010). In response to the increased popularity of archery hunting and establishment of limited entry rifle seasons in

Received: 31 May 2011; Accepted: 11 April 2012

Published: 15 June 2012

Additional supporting information may be found in the online version of this article.

${ }^{1}$ E-mail: greg.a.davidson@state.or.us northeast Oregon, the number of archers in some management units increased $>220 \%$ during the last 10 years (Oregon Department of Fish and Wildlife 2003), with archer densities estimated to be $>1.2$ archers $/ \mathrm{km}^{2}$ ( 3 archers/ $\left.\mathrm{mi}^{2}\right)$ in some units. A concern that archery elk hunting during the elk-breeding season (rut) may negatively affect elk reproduction was identified in Oregon's Elk Management Plan (Oregon Department of Fish and Wildlife 1992).

Conception dates of female elk may be affected by mature male abundance (Noyes et al. 1996, 2002), female nutritional condition (Trainer 1971, Mitchell and Lincoln 1973, Hines and Lemos 1979, Albon et al. 1986, Cook et al. 2004a), and human activity during the rut (Squibb 1985). Squibb et al. (1986) reported a sudden drop in conceptions coinciding with the opening of rifle elk seasons and speculated that the mechanism for the disruption of elk reproduction likely involved females, rather than males. Possible mechanisms 
of stress-induced conception delays were reduced ovulation rate, suppression of behavioral estrus, and early death of embryos. Squibb et al. (1986) also reported that stress from hunting did not reduce pregnancy rates, but did delay conception.

Hunting pressure has been shown to cause increased movement of elk (Conner et al. 2001, Vieira et al. 2003, Johnson et al. 2004, Davidson 2007), and the ensuing energy cost or displacement could reduce breeding during the first or subsequent estrus cycles. Johnson et al. (2004) estimated a $4-10 \%$ increase in the normal daily energy expenditure of elk because of movement caused by hunters at an average daily density of 0.91 hunters $/ \mathrm{km}^{2}$. Greater energetic demands coupled with movement away from prime habitat and/or less time to feed immediately preceding or during the rut could affect pregnancy rates.

Body fat effects on pregnancy rates in ungulates are well documented (Trainer 1971, Cameron et al. 1993, Kohlmann 1999); elk with at least moderate summer and early autumn nutrition typically have $>90 \%$ probability of breeding (Cook et al. 2001b, 2004a). Additionally, short-term (i.e., 4 days to 3 weeks prior to breeding) nutrition (nutrient flushing) can contribute to ovulation in ungulates (National Research Council 1985, I'Anson et al. 1991, Molle et al. 1995, Martin et al. 2004). Likewise, late summer and autumn nutrition can affect conception dates and pregnancy rates in elk (Cook et al. 2004a, b).

Archery seasons in Oregon begin the last Saturday of August and continue for 30 days, overlapping the peak of the rut for elk. Our goal was to evaluate the effects of archery hunting disturbance on elk reproduction in a closed, but freeranging, elk population when males $\geq 3$ years of age were present. We compared pregnancy rates and conception dates of female elk subjected to varying densities of archery hunters during the rut.

\section{STUDY AREA}

We conducted this study from 1991 to 1993 and 1997-2006 in the main study area $(7,770 \mathrm{ha})$ at the United States Forest Service Starkey Experimental Forest and Range (Starkey), located $35 \mathrm{~km}$ southwest of La Grande in northeast Oregon. Elevation ranged from $1,116 \mathrm{~m}$ to $1,502 \mathrm{~m}$. The study area was enclosed by a game-proof fence $2.6 \mathrm{~m}$ tall (Rowland et al. 1997). The suite of large predators present included black bears (Ursus americanus), cougars (Puma concolor), coyotes (Canis latrans), and bobcats (Felis rufus). Vegetation was a mosaic of forest stands and open areas. Ponderosa pine (Pinus ponderosa) was the dominant forest vegetation at lower elevations and lodgepole pine ( $P$. contorta), grand fir (Abies grandis), and Douglas-fir (Pseudotsuga menziesii) dominated northerly aspects and higher elevations. Bluebunch wheatgrass (Agropyron spicatum) and Idaho fescue (Festuca idahoensis) dominated grassland vegetation. Annual precipitation averaged $50.4 \mathrm{~cm}$, and average mean temperatures were $18^{\circ} \mathrm{C}$ in July and $-4^{\circ} \mathrm{C}$ in January. More detailed descriptions of the study area can be found by Noyes et al. (1996) and Rowland et al. (1997).

\section{METHODS}

\section{Herd Management}

We estimated population size and composition with methods described by Noyes et al. $(1996,2002)$. We validated the population estimates from 18 helicopter surveys using Idaho sightability models (Unsworth et al. 1994). During winters, elk that moved to the winter feedground were fed 3.5$5.5 \mathrm{~kg} / \mathrm{elk} /$ day of alfalfa hay. The numbers of elk on the winter feedground were determined from the records of elk handled as they entered the feedground. Our objective was to minimize the influence of variable winter severity on elk reproduction by returning animals to the study area in similar nutritional condition each year (Rowland et al. 1997).

Without mature males present, conception dates have been shown to be later and asynchronous (Noyes et al. 1996, 2002). To increase the likelihood that mature males were responsible for the breeding, we annually conducted 5- to 7day-long hunts for yearling male elk in early to mid-August. During the winters of 1991-1993 and 1996-1999, while conducting a breeding male elk study (Noyes et al. 1996, 2002), we also removed juvenile and yearling males from the study area that were trapped on the winter feedground or in dispersed portable traps.

\section{Archer Densities}

To replicate hunting conditions in adjacent wildlife management units, we scheduled archery seasons to coincide with statewide seasons, and we set the maximum density of archers similar to the estimated archer densities in adjacent wildlife management units. We varied hunting tags available from a maximum density of $1.15 \mathrm{tags} / \mathrm{km}^{2}$ for 4 years (20002002, 2006), to a minimum density of $0.51 \mathrm{tags} / \mathrm{km}^{2}$ for 3 years (2003-2005; Table 1). Six years (1991-1993, 19971999) were associated with the breeding male elk studies (Noyes et al. 1996, 2002) in which no archery hunts occurred. The original study plan required 3 consecutive years each of high archer densities and low archer densities, which we selected randomly. To increase sample size of elk subjected to high archer density, we added an additional high archer density year. We staffed a check station with project personnel or volunteers to record archery hunter presence in Starkey. If the check station was not staffed, archers signed themselves in and out of Starkey. We also collected questionnaires from archers to estimate the number of days they hunted. We calculated the average number of archers per day during each archery season.

Table 1. Number of archers and archer densities during archery season at the Starkey Experimental Forest and Range, Oregon, USA, 2000-2006.

\begin{tabular}{|c|c|c|c|c|}
\hline Year & Archers & $\begin{array}{c}\text { Mean daily } \\
\text { archer density } \\
\text { (hunters } / \mathbf{k m}^{2} \text { ) }\end{array}$ & SD & $\begin{array}{c}\text { Total } \\
\text { tags sold } \\
\left(\text { tags } / \mathbf{k m}^{2}\right)\end{array}$ \\
\hline 2000 & 85 & 0.41 & 0.12 & 1.09 \\
\hline 2001 & 84 & 0.41 & 0.06 & 1.08 \\
\hline 2002 & 89 & 0.44 & 0.13 & 1.15 \\
\hline 2003 & 40 & 0.16 & 0.08 & 0.51 \\
\hline 2004 & 42 & 0.17 & 0.07 & 0.54 \\
\hline 2005 & 43 & 0.22 & 0.05 & 0.55 \\
\hline 2006 & 81 & 0.36 & 0.09 & 1.04 \\
\hline
\end{tabular}




\section{Reproductive Data}

Each year, we conducted antlerless elk rifle hunts during the first week of December and staffed a hunter check station for all days of the hunts. We collected reproductive tracts (uteri and ovaries), udders, lower incisors, and kidneys with associated fat from elk harvested by hunters. We based cow condition estimates on a modified kidney fat index (KFI) described by Trainer (1971). We determined conception dates, pregnancy status, lactation status, and age using methods described by Noyes et al. (1996).

Though we trimmed and evaluated KFI in a consistent manner across all years (with only 1 observer doing the evaluation), this technique may be prone to observer bias (Cook et al. 2007). Judging what fat belongs to the kidneys and what fat belongs to adjacent internal organs can be difficult, so the potential for error in estimating body fat values based on equations from Cook et al. (2001a) is high. Therefore, we did not convert KFI to ingesta-free body fat, but instead used raw KFIs because a relative index of body fat was sufficient for our analysis.

\section{Statistical Analysis}

We transformed dates of conception (reciprocal square root) to improve normality. We used $P=0.050$ as the level of significance for all tests. We compared conception dates and pregnancy rates for lactating and non-lactating elk $\geq 2$ years old among treatments (archer densities) with analysis of variance (ANOVA) and Fisher's least significant difference (LSD) for multiple comparisons (version 9.2; SAS Institute, Inc., Cary, NC). We calculated the coefficient of determination $\left(R^{2}\right)$ to determine the ability of pregnancy rates to predict the following year post-hunt modeled juvenile:female ratio.

We used a hypothesis testing framework, allowing us to first test for differences among treatment groups. We next used an information theoretic approach using generalized linear models (GLM) and logistic regression to quantify effect size of biotic and abiotic covariates (including archer densities) and compare estimates relative to pregnancy rates and conception dates. By using this mixed paradigm approach, we were able to examine differences in treatments and then compare model estimates between treatments. We modeled date of conception of females $\geq 2$ years old using GLM (PROC GLM; SAS Institute, Inc.), and modeled pregnancy rates of females $\geq 2$ years old using logistic regression. We pooled reproductive data across years after first determining pregnancy rates and conception dates did not differ by year. To determine if a threshold of archer density affected elk reproduction, we evaluated archer density by pooling high and low density (high-low), low density and no archers (low-none), and by evaluating all 3 groups individually (high, low, and none). We included these archer densities as a group covariate and included age, age $>13$ years old (binomial), lactation status, and lognormally distributed (ln) KFI as individual covariates. We used $\ln (\mathrm{KFI})$ because the relationship between KFI and body fat is logarithmic (Cook et al. 2001a). We next added the ratio of adult males $\geq 3$ years old to females $\geq 2$ years old (male:female), cumu- lative December-March snowfall, and cumulative 15 July-15 October precipitation to each of the previous 22 a priori models.

Noyes et al. (1996, 2002) demonstrated that conception dates were earlier when breeding was by males $\geq 3$ years old; therefore, we used males $\geq 3$ years old rather than all males. We used precipitation as a proxy for forage production before and during the breeding season (15 Jul-15 Oct). We used Akaike's Information Criterion, adjusted for small samples $\left(\mathrm{AIC}_{c}\right)$, for model selection (Burnham and Anderson 2002). If including a covariate resulted in an increase in $\mathrm{AIC}_{c}$ score approximately 2 units greater than the same model without the extra parameter, and the deviance remained virtually unchanged (indicating the covariate did not contribute useful information), we dropped the model with the uninformative parameter from the model list (Arnold 2010).

We used PROC CORR (SAS Institute, Inc.) to examine correlations between precipitation and $\ln (\mathrm{KFI})$. We used the Hosmer-Lemeshow goodness-of-fit test to examine relationships between KFI (continuous variable) and lactation status (binomial variable). A good model fit would be expected if the 2 variables were correlated. To determine at what KFI level the models predicted elk to be affected, we first varied KFI levels from minimum to maximum measured, and then compared model averaged estimates for the 3 archer densities for lactating and non-lactating elk while holding other parameters at their mean values. We considered a difference in conception date or pregnancy rate estimates significant if the interval $\left(\hat{\boldsymbol{\Theta}}_{1}-\hat{\boldsymbol{\Theta}}_{2}\right) \pm 1.96 \sqrt{\operatorname{var} \hat{\boldsymbol{\Theta}}_{1}+\operatorname{var} \hat{\boldsymbol{\Theta}}_{2}-2 \rho \mathrm{SE} \hat{\boldsymbol{\Theta}}_{1} \mathrm{SE} \hat{\boldsymbol{\Theta}}_{2}} \operatorname{did}$ not overlap zero (Schenker and Gentleman 2001), where $\hat{\Theta}_{x}=$ point estimate and $\rho=$ correlation coefficient. Since the sets of elements used to compute the 2 estimates being compared overlapped, we expected a positive correlation. This method adjusts for the high Type I error rates that can occur from multiple, correlated comparisons using confidence interval overlap to determine significance.

To validate our models, we used data collected during fall 2001-2007 from 83 elk (KFI, pregnancy status, lactation status, and age) harvested by hunters in the Sled Springs Wildlife Management Unit in northeast Oregon (B. K. Johnson, Oregon Department of Fish and Wildlife, unpublished data). Sled Springs is approximately $100 \mathrm{~km}$ from Starkey, with larger areas of grand fir-dominated forests and wet meadows (resulting from greater precipitation than Starkey; Coe et al. 2011). Further comparisons of the 2 study areas are described by Coe et al. (2011). We derived precipitation data by averaging July-September precipitation at 3 points within the summer range of the sampled elk (PRISM Climate Group 2010). We estimated pregnancy rates using models from the pregnancy rate analysis and generated model averaged estimates of pregnancy rate for each archer density group for each sampled elk. We then bootstrapped these estimates (10,000 repetitions) to generate a mean and $95 \%$ confidence interval for each archer density and compared estimated pregnancy rates with known pregnancy rates. 
Our research was conducted following review and approval by the Starkey Institutional Animal Care and Use Committee, as required by the Animal Welfare Act of 1985 and its regulations. We specifically followed protocols established by the Starkey Institutional Animal Care and Use Committee for conducting deer and elk research at Starkey (Wisdom et al. 1993).

\section{RESULTS}

\section{Herd Management}

Males $\geq 3$ years old were estimated at ratios of $7-48$ per 100 females at the end of the rut (Fig. 1), and estimates of female population size ranged from 370 to 669 (Fig. 2) at the end of winter (Noyes et al. 1996, 2002; B. K. Johnson, unpublished data). The mean number of cow elk $\geq 2$ years old on the winter feedground was 73 (range $=1-140$, $\mathrm{SD}=42$ ), which corresponded to an average of $26.7 \%$ (range $=0.4-44.0, \mathrm{SD}=13.5$ ) of the annual population estimate of the same age class. Mean snowfall from December to March was $9.8 \mathrm{~cm}$ (range $=2.5-16.2$, $\mathrm{SD}=4.5)$ and was a marginal predictor of the percentage of female elk $\geq 2$ on the winter feedground $\left(R^{2}=0.42\right)$. Pregnancy rates explained little of the variation $\left(R^{2}=0.20\right)$ in the following year post-hunt modeled juvenile:female ratio.

\section{Harvest}

During the 7 years of archery hunts, 464 archers participated (low density $\bar{x}=0.183$ archers $/ \mathrm{km}^{2} /$ day, $\mathrm{SD}=0.032$; high density $\bar{x}=0.40$ archers $/ \mathrm{km}^{2} /$ day, $\mathrm{SD}=0.033$; Table 1 ). During the 13 years of December antlerless elk hunts, 622 female elk were harvested $(\bar{x}=47.9$ per year, $\mathrm{SD}=9.6)$.

\section{Female Condition}

We found KFI differed among archer densities for pregnant elk $\geq 2$ years old $\left(F_{2,404}=9.68 ; P<0.001\right)$ and all female elk $\geq 2$ years old $\left(F_{2,447}=12.59 ; P<0.001\right)$, with the greatest KFI levels associated with years of no archery hunters (Table 2). Non-lactating elk had greater KFI than lactating elk $(P<0.001$ for both elk data groups; Table 2$)$. The Hosmer-Lemeshow test for lactation and KFI yielded a $\chi^{2}$ of $18.0(P=0.02)$, indicating a poor model fit and suggesting that KFI and lactation rate were not highly correlated.

\section{Pregnancy Rate}

Mean pregnancy rate for all female elk $\geq 2$ years old was $0.868(n=448, \mathrm{SE}=0.016)$ across all years (Fig. 3), 0.951 $(n=223, \mathrm{SE}=0.022)$ for non-lactating elk, and 0.787 $(n=225, \mathrm{SE}=0.022)$ for lactating elk. Pregnancy rates in our study were below $90 \%$ in 7 of 13 years. Four of these years were high archer density years, 1 was associated with low archer density, and 2 were years with no archers (Fig. 3).

Pregnancy rates differed among treatments (no archers $=$ 0.909 , low archer density $=0.888$, high archer density $=$ $0.804 ; F_{2,447}=4.39, P=0.013$; Table 3). Pregnancy rates differed between high archer density and no archer years (0.105 difference; $P=0.004$ ) but did not differ between high archer density and low archer density years $(0.084$ difference; $P=0.054)$ or between low archer density and no archer years (0.021 difference; $P=0.616)$. Controlling for lactation status, pregnancy rates differed among treatments $\left(F_{5,442}=10.08, P<0.001\right)$, but differed only for the comparisons of lactating-high archer density to lactating-low archer density (0.167 difference; $P=0.008)$ and lactatinghigh archer density to lactating-no archers (0.224 difference; $P<0.001)$.

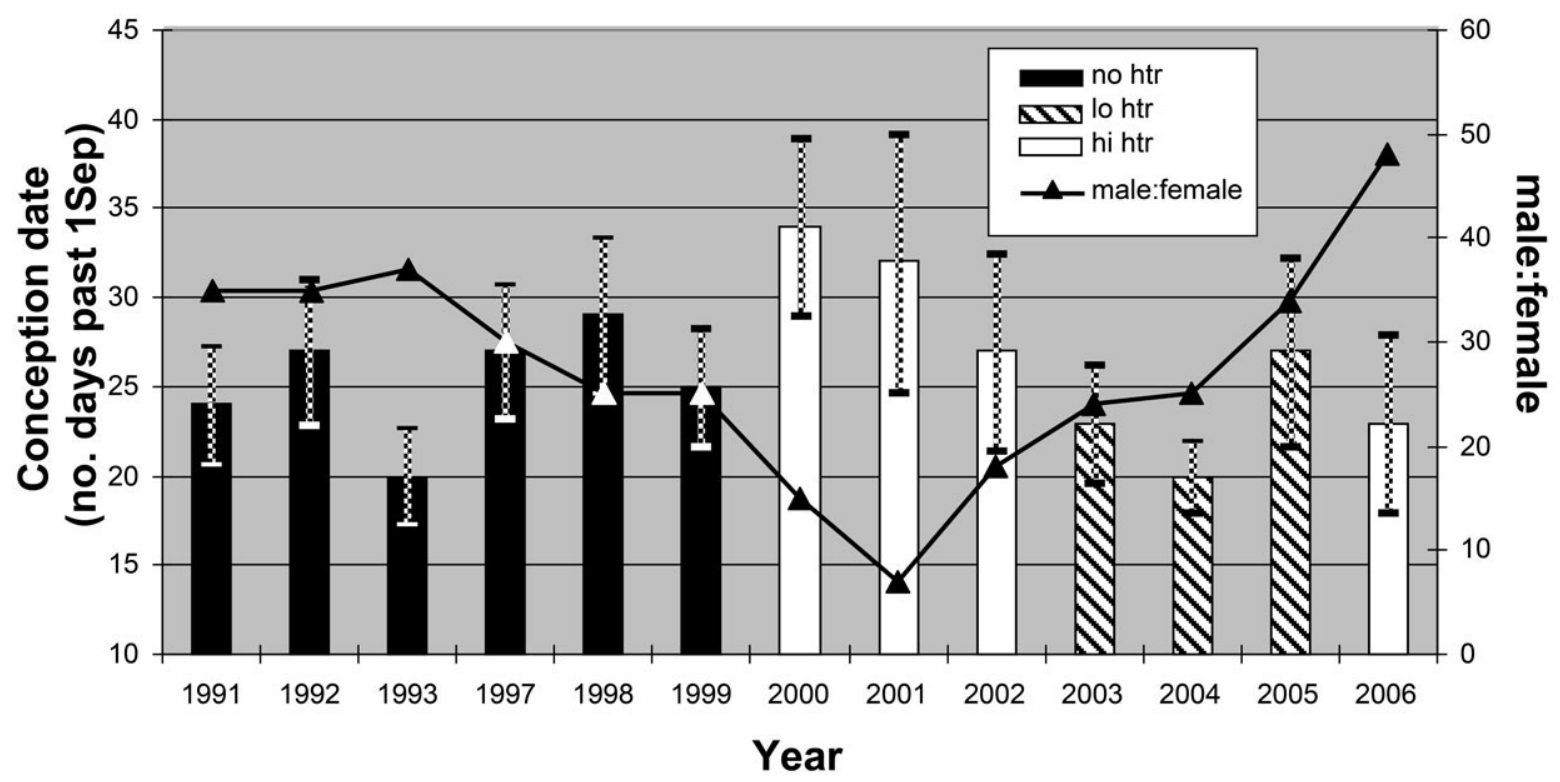

Figure 1. Conception dates and male ( $\geq 3 \mathrm{yr}$ ) to 100 female ( $\geq 2 \mathrm{yr}$ ) ratio of elk subjected to 3 levels of archer density during the rut at the Starkey Experimental Forest and Range, Oregon, USA, 1991-1993 and 1997-2006. No htr = no archers; hi htr = high archer density; lo htr = low archer density; and male: female $=$ number of male elk $\geq 3$ years old to 100 female elk $\geq 2$ years old. 


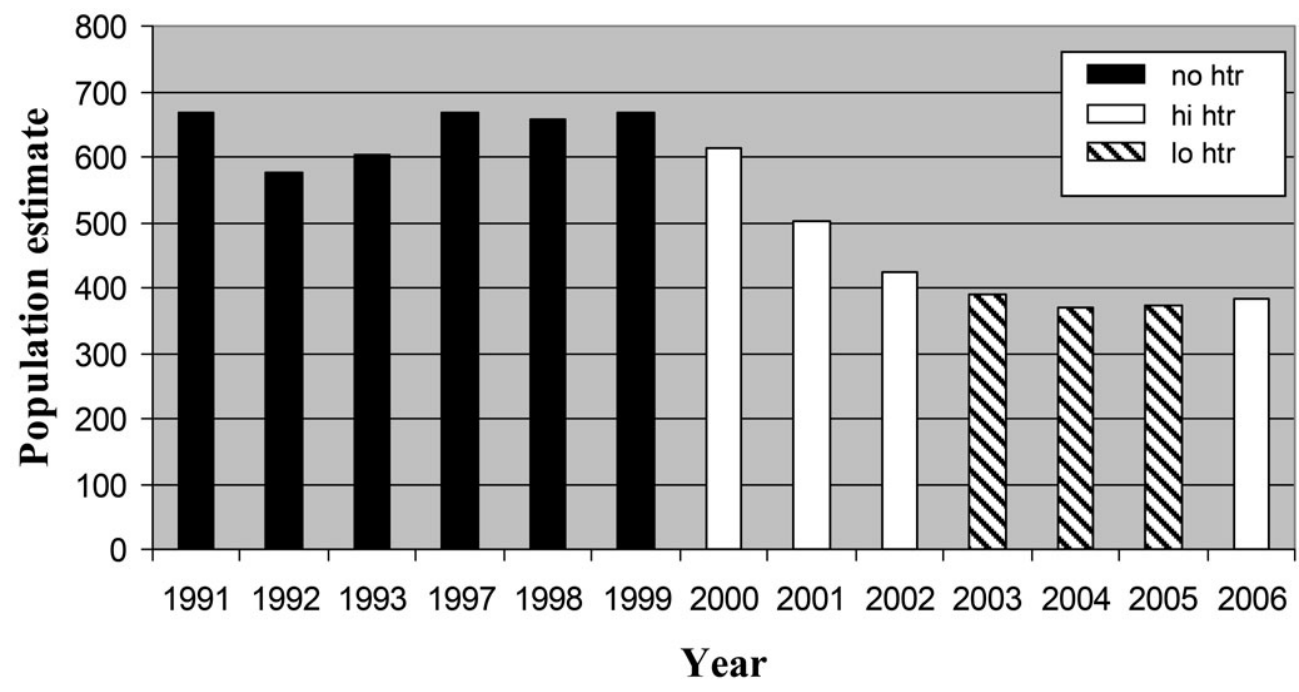

Figure 2. Population estimates of elk subjected to 3 levels of archer density during the rut at the Starkey Experimental Forest and Range, Oregon, USA, 1991-1993 and 1997-2006. No htr = no archers; hi htr = high archer density; and lo htr = low archer density.

Of the 47 models we evaluated (see Appendix 1, available online at www.onlinelibrary.wiley.com), we used 13 models to derive model-averaged pregnancy rate estimates; these accounted for $92.2 \%$ of the available model weight. Eleven of these models included archer density and all 13 included $\ln (\mathrm{KFI})$ and precipitation covariates (Table 4). The interaction term for $\ln (\mathrm{KFI})$ and archer density was in 5 of the 13 models used for model averaging; these 5 models accounted for $46.4 \%$ of the model weight. Models containing adult male to female ratio and December-March snowfall did not improve more parsimonious models; therefore, we dropped models containing these covariates from the candidate models (Arnold 2010). Models containing only a year effect or trend had virtually no model weight.

The influences of archer density on pregnancy rate was strongest for lactating females with lower than average KFI. After varying KFI levels and comparing model-averaged estimates for lactating females, KFI levels of 76 (28th percentile) and lower resulted in a significant difference in pregnancy rates when comparing high archer densities to low and no archer densities. Specifically, 28\% of the lactating female elk were estimated to be affected by high archer density. No KFI levels for non-lactating females resulted in a significant difference in model estimates for the same comparisons.

\section{Conception Date}

Mean conception dates differed across treatments (no archers $=24$ Sep, low archer density $=22$ Sep, high archer density $=26 \mathrm{Sep} ; F_{2,401}=3.84, P=0.022$; Fig. 1 , Table 5). Conception dates were 4 days later for high archer density compared to low archer density $(P=$ $0.006)$, but did not differ between high and no archer years ( 2 days; $P=0.136$ ) or between low and no archer years (2 days; $P=0.108$ ). Controlling for lactation status, mean conception date differed across treatments $\left(F_{5,398}=13.33\right.$, $P<0.001)$ and for the comparisons of lactating-high archer density to lactating-low archer density (11 days difference; $P<0.001)$ and lactating-high archer density to lactating-no archers ( 8 days difference; $P<0.001$ ).

Among 69 GLM models (see Appendix 2, available online at www.onlinelibrary.wiley.com), we derived modelaveraged estimates from 7 models, which accounted for $97.7 \%$ of the model weight. Six of these models contained archer density, and all models contained lactation, precipitation, age, and age $>13$ years old covariates (Table 6). Male:female ratio was in the top 2 models, which accounted for $86 \%$ of the model weight. None of the non-hunterrelated covariates explained the earlier conception dates occurring in the low archer density years as opposed to the expected results of earliest conception dates occurring in

Table 2. Population estimates, mean age, and mean kidney fat index (KFI) of female elk ages 2- to 21-year old subjected to no (1991-1993, 1997-1999), low (2003-2005), and high archer density (2000-2002, 2006) at Starkey Experimental Forest and Range, Oregon, USA. Lact = lactating, nonlact = non-lactating.

\begin{tabular}{|c|c|c|c|c|c|c|c|c|c|c|c|c|c|}
\hline \multirow{2}{*}{$\begin{array}{l}\text { Archer } \\
\text { density }\end{array}$} & \multirow{2}{*}{$\begin{array}{l}\text { Population } \\
\text { females } \geq 2\end{array}$} & \multicolumn{6}{|c|}{ Female elk ages 2-21 } & \multicolumn{6}{|c|}{ Pregnant elk ages 2-21 } \\
\hline & & KFI all elk & KFI lact & $n$ & KFI nonlact & $n$ & $\overline{\bar{x} \text { Age }}$ & KFI all elk & KFI lact & $n$ & KFI nonlact & $n$ & $\bar{x}$ Age \\
\hline 0 & 304 & $153.5 \mathrm{~A}^{\mathrm{a}}$ & 114.7 & 113 & 205.7 & 84 & 6.1 & $160.9 \mathrm{~A}^{\mathrm{a}}$ & 122.6 & 99 & 206.0 & 84 & 5.8 \\
\hline Low & 199 & $115.2 \mathrm{~B}$ & 71.8 & 42 & 147.7 & 56 & 5.8 & $123.8 \mathrm{~B}$ & 87.0 & 39 & 149.9 & 55 & 5.8 \\
\hline High & 259 & $120.1 \mathrm{~B}$ & 77.5 & 70 & 156.1 & 83 & 6.5 & $135.0 \mathrm{~B}$ & 90.9 & 44 & 158.9 & 81 & 6.4 \\
\hline All & 266 & 133.7 & 95.1 & 225 & 172.7 & 223 & 6.2 & 133.9 & 107.3 & 182 & 174.6 & 220 & 6.0 \\
\hline
\end{tabular}

${ }^{a}$ Means with dissimilar letters were different. 


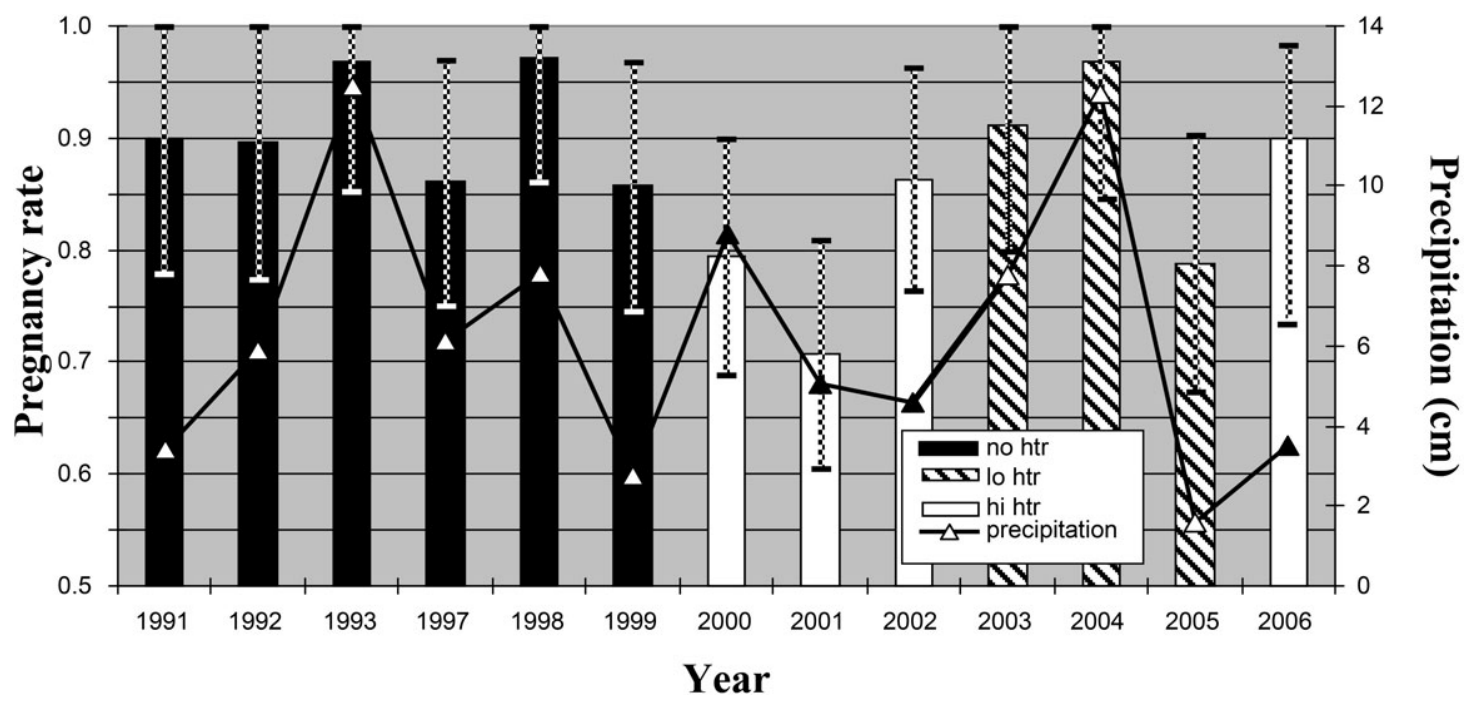

Figure 3. Precipitation (15 Jul-15 Oct) and annual mean pregnancy rates for female elk 2- to 21-year old subjected to 3 levels of archer density during the rut at the Starkey Experimental Forest and Range, Oregon, USA, 1991-1993 and 1997-2006. We collected reproductive tracts during December antlerless elk hunts. No htr = no archers; hi htr = high archer density; and lo htr = low archer density.

years with no archers. Consequently, estimates from model averaging predicted earlier conception dates for low archer years than for years with no archers for both lactating and non-lactating elk. For lactating and non-lactating females, we found no significant differences for model estimates of conception dates between high versus no archer densities or between high and low archer densities for any KFI level.

\section{Model Validation}

For 83 female elk (2- to19-yr old) sampled in a previous study (B. K. Johnson, unpublished data), the pregnancy rate was $0.892(\mathrm{SE}=0.034)$ for an area with an estimated archer density less than the low density in our study (0.13 archers/ $\mathrm{km}^{2}$; J. A. Hurtado, Oregon Department of Fish and Wildlife, personal communication). The predicted pregnancy rate of these same elk using our models was 0.915 (95\% CI: 0.891-0.936) for low archer density. Pregnancy rate using the high archer density in the model was predicted to be 0.851 (95\% CI: $0.838-0.865$ ).

\section{DISCUSSION}

\section{Effects of Archer Density}

Our results suggest a density of archery hunters $\geq 0.41$ archhers $/ \mathrm{km}^{2}$ during the rut, combined with lower than average KFI of lactating elk, would result in reduced pregnancy rates for elk. Patterns we observed are consistent with previous studies that showed significant relationships among KFI, lactation status, and pregnancy levels in elk (Kohlmann 1999; Cook et al. 2001b, 2004b). Additionally, the male: female ratio was not a significant covariate in our analysis, which did not support the alternative hypothesis of depressed pregnancy rates caused by a scarcity of mature breeding bulls.

Gerhart et al. (1997) reported a difference in pregnancy rates between lactating and non-lactating caribou (Rangifer tarandus granti) at low fat levels. In our study, confidence intervals of pregnancy rate estimates by lactation status at low KFI levels were large because of large variances, likely because of small sample sizes at low KFI levels (Fig. 4), making detecting differences difficult.

During years with no archery hunting, yearling male hunts were later (started near 15 Aug vs. 1 Aug), longer (9 days vs. 5 days), had more hunters ( $\bar{x}=128$ vs. $\bar{x}=92)$, and harvested more elk $(\bar{x}=28$ vs. $\bar{x}=15)$ when compared to years with archery hunting; this did not support the hypothesis that the yearling elk hunts adversely affected pregnancy rates or conception dates. Likewise, population estimates were greater for the years of no archery hunting (Fig. 3), which did not support density dependence as a contributing factor affecting pregnancy rates or conception dates.

Lactating females conceived later, similar to results from Trainer (1971), in which lactating Roosevelt elk (C. elaphus roosevelti) conceived later than non-lactaters. Although our

Table 3. Pregnancy rates for female elk 2- to 21-year old subjected to no (1991-1993, 1997-1999), low (2003-2005), and high archer density (2000-2002, 2006) at Starkey Experimental Forest and Range, Oregon, USA. We collected reproductive tracts during December antlerless elk hunts.

\begin{tabular}{llrrrrrrrr}
\hline & \multicolumn{1}{c}{ Pregnancy rate } \\
\cline { 2 - 9 } Archer density & All elk & \multicolumn{1}{c}{ SE } & Lactating & $\boldsymbol{n}$ & \multicolumn{1}{c}{ SE } & Non-lactating & $\boldsymbol{n}$ & SE \\
\hline 0 & $0.909 \mathrm{~A}^{\mathrm{a}}$ & 197 & 0.024 & $0.867 \mathrm{~A}$ & 113 & 0.030 & $0.964 \mathrm{~A}$ & 84 \\
Low & $0.888 \mathrm{AB}$ & 98 & 0.034 & $0.810 \mathrm{~A}$ & 42 & 0.050 & $0.946 \mathrm{~A}$ & 56 & 0.043 \\
High & $0.804 \mathrm{~B}$ & 153 & 0.027 & $0.643 \mathrm{~B}$ & 70 & 0.039 & $0.940 \mathrm{~A}$ & 83 & 0.035 \\
\hline
\end{tabular}

${ }^{a}$ Means with dissimilar letters were different. 
Table 4. Top ranked models using Akaike's Information Criteria for small sample size $\left(\mathrm{AIC}_{c}\right)$ model selection for logistic regression models applied to pregnancy rates of female elk 2- to 21-year old at the Starkey Experimental Forest and Range, Oregon, 1991-1993 and 1997-2006. LnKFI = ln(kidney fat index), lact $=$ lactation status, precip $=15$ July-15 Oct precipitation, $>13=$ binomial variable for elk $>13$ years old, den $=$ mean daily archer density, hi $=$ high archer density group, lo $=$ low archer density group, no $=$ no archer density group, and low/no $=$ pooled low and no archer density groups. Difference between $\mathrm{AIC}_{c}$ and that of the top model $\left(\Delta \mathrm{AIC}_{c}\right)$, Akaike's weight $\left(w_{i}\right)$, log-likelihood $(\mathrm{LL})$, and number of parameters $(K)$ are reported.

\begin{tabular}{|c|c|c|c|c|}
\hline Model & $\Delta \mathrm{AIC}_{c}$ & $w_{i}$ & $\mathbf{L L}$ & $K$ \\
\hline $\operatorname{den}($ lo $/$ no, hi $)+$ lact + precip $+\operatorname{lnKFI}+>13+$ age $+\operatorname{lnKFI} \times \operatorname{den}$ & 0.0 & 0.184 & 1.000 & 8 \\
\hline $\operatorname{den}($ lo $/$ no, hi $)+$ lact + precip $+\operatorname{lnKFI}+>13+\operatorname{lnKFI} \times \operatorname{den}$ & 0.5 & 0.144 & 0.782 & 7 \\
\hline $\operatorname{den}($ lo $/$ no, hi $)+$ lact + precip $+\operatorname{lnKFI}+>13+$ age & 0.7 & 0.127 & 0.692 & 7 \\
\hline $\operatorname{den}($ lo $/$ no, hi $)+$ lact + precip $+\operatorname{lnKFI}+>13$ & 1.2 & 0.099 & 0.537 & 6 \\
\hline $\operatorname{den}($ lo, no, hi $)+$ lact + precip $+\operatorname{lnKFI}+>13+$ age & 1.6 & 0.081 & 0.443 & 8 \\
\hline $\operatorname{den}($ lo, no, hi $)+$ lact + precip $+\operatorname{lnKFI}+>13+$ age $+\operatorname{lnKFI} \times \operatorname{den}$ & 2.3 & 0.059 & 0.320 & 10 \\
\hline $\operatorname{den}($ lo, no, hi $)+$ lact + precip $+\operatorname{lnKFI}+>13+\operatorname{lnKFI} \times \operatorname{den}$ & 2.4 & 0.054 & 0.295 & 9 \\
\hline $\operatorname{den}($ lo, no, hi $)+$ lact + precip $+\operatorname{lnKFI}+>13$ & 2.5 & 0.052 & 0.285 & 7 \\
\hline $\operatorname{den}(\mathrm{lo} /$ no, hi $)+$ lact + precip $+\operatorname{lnKFI}$ & 2.7 & 0.047 & 0.255 & 5 \\
\hline $\operatorname{den}(l o$, no, hi $)+$ lact $+\operatorname{lnKFI}+$ precip & 3.7 & 0.029 & 0.156 & 6 \\
\hline $\operatorname{den}($ lo $/$ no, hi $)+$ lact + precip $+\operatorname{lnKFI}+$ age $+\operatorname{lnKFI} \times$ den & 4.1 & 0.024 & 0.129 & 7 \\
\hline lact + precip $+\operatorname{lnKFI}+>13$ & 5.5 & 0.012 & 0.063 & 5 \\
\hline lact + precip $+\operatorname{lnKFI}+>13+$ age & 5.7 & 0.011 & 0.059 & 6 \\
\hline Intercept & 84.5 & 0.000 & 0.000 & 1 \\
\hline
\end{tabular}

results suggested conception dates for lactating elk were affected by high archer densities (Table 5), poor precision precluded significant results when comparing model estimates. The inclusion of male:female ratio in the top ranked models supports the findings of Noyes et al. (1996, 2002), who demonstrated that conception dates were earlier when breeding was by males $\geq 3$ years old. Likewise, the inclusion of precipitation, $\ln (\mathrm{KFI})$, and lactation status were consistent with previous studies linking earlier conception dates with high female nutritional condition (Trainer 1971, Mitchell and Lincoln 1973, Hines and Lemos 1979, Albon et al. 1986, Cook et al. 2004a).

\section{Interactions With Nutrition and Weather}

The inclusion of precipitation in all of the top models indicated summer nutrition affected pregnancy rates and conception dates, with greater pregnancy rates and earlier conception dates associated with increased precipitation. Inadequate nutrition during winter and spring, resulting in delayed parturition, has been reported for elk (Cook et al. 2004a), white-tailed deer (Odocoileus virginianus; Verme 1965), moose (Alces alces; Schwartz and Hundertmark 1993), and caribou (Skogland 1983, Cameron et al. 1993). Through winter feeding, we reduced effects caused by harsh winter conditions by feeding, on average, $26.7 \%$ of the female elk $\geq 2$ years. The fact that winter snowfall was not informative in our models suggests that winter range at Starkey met nutritional needs, winter conditions were much milder compared to severe winter conditions reported for other winter ranges of elk (Coughenour and Singer 1996, Loison and Lagvatn 1998, Garrott et al. 2003), or we were successful in minimizing effects through winter feeding.

The largest effect of archery hunting in our study was on lactating females with reduced KFI levels. Rearden (2005) found that predation was the main factor in juvenile elk survival in northeast Oregon, with the majority of predation on neonates occurring in the first 3 months following birth. Cook et al. (2004b) demonstrated females that lose their neonate in summer, and thus do not have the nutritional demand of lactation, regain sufficient body fat and mass similar to non-lactating females. Females that lose neonates in summer may regain KFI levels that are sufficient to limit the effect of archer densities on pregnancy rates. Given the presence of black bear and cougar predation on neonate elk at Starkey, our observation of the relatively poor fit of pregnancy rates to following year juvenile:female ratios was not surprising. In areas with lower densities of black bears and cougars, high archer density may have a greater effect on juvenile:female ratios in management units where nutrition of lactating females is low.

\section{Model Validation}

Predictions from our model validations of pregnancy rates for elk in northeast Oregon, compared to empirical estimates of pregnancy rates, suggested that our pregnancy rate estimators for elk are useful in northeast Oregon (predicted rate of 0.915 vs. observed value of 0.892 , with overlapping CIs). Ideally, we would have used data from an area of high archer densities

Table 5. Mean conception dates of lactating and non-lactating female elk subjected to no (1991-1993, 1997-1999), low (2003-2005), and high archer density (2000-2002, 2006) at Starkey Experimental Forest and Range, Oregon, USA. Conc $=$ conception.

\begin{tabular}{|c|c|c|c|c|c|c|c|c|c|}
\hline \multirow[b]{2}{*}{ Archer density } & \multicolumn{3}{|c|}{ All elk } & \multicolumn{3}{|c|}{ Lactating } & \multicolumn{3}{|c|}{ Non-lactating } \\
\hline & Conc date & $n$ & $\overline{\mathrm{SE}}$ & Conc date & $n$ & $\overline{\mathrm{SE}}$ & Conc date & $n$ & SE \\
\hline 0 & $24 \mathrm{Sep} \mathrm{AB}^{\mathrm{a}}$ & 184 & 0.97 & $27 \mathrm{Sep} \mathrm{A}^{\mathrm{a}}$ & 98 & 1.27 & $22 \operatorname{Sep}^{\mathrm{a}}$ & 86 & 1.36 \\
\hline Low & 22 Sep B & 94 & 1.35 & 24 Sep A & 39 & 2.01 & 21 Sep A & 55 & 1.70 \\
\hline High & 26 Sep A & 126 & 1.17 & 5 Oct B & 44 & 1.90 & 22 Sep A & 82 & 1.39 \\
\hline
\end{tabular}

${ }^{a}$ Means with dissimilar letters were different. 
Table 6. Top ranked models using Akaike's Information Criteria for small sample size $\left(\mathrm{AIC}_{c}\right)$ model selection for generalized linear models regression applied to conception dates of female elk 2- to 21-year old at the Starkey Experimental Forest and Range, Oregon, 1991-1993 and 1997-2006. LnKFI = $\ln ($ kidney fat index), lact $=$ lactation status, precip $=15$ July -15 October precipitation $(\mathrm{mm}),>13=$ binomial variable for elk $>13$ years old, male:female $=$ number of males $\geq 3$ years per 100 females $\geq 2$ years, den $=$ mean daily archer density, hi $=$ high archer density group, lo $=$ low archer density group, no $=$ no archer density group, hi/lo = pooled high and low archer density groups, and low/no = pooled low and no archer density groups. Difference between $\mathrm{AIC}_{c}$ and that of the top model $\left(\Delta \mathrm{AIC}_{c}\right)$, Akaike's weight $\left(w_{i}\right), \log$-likelihood $(\mathrm{LL})$, and number of parameters $(K)$ are reported.

\begin{tabular}{|c|c|c|c|c|}
\hline Model & $\Delta \mathrm{AIC}_{c}$ & $w_{i}$ & LL & $K$ \\
\hline $\operatorname{den}($ lo, no, hi $)+$ lact + precip + male:female $+\operatorname{lnKFI}+>13+$ age & 0.0 & 0.553 & 1.00 & 9 \\
\hline $\operatorname{den}($ lo, no, hi $)+$ lact + precip + male:female $+\operatorname{lnKFI}+>13+$ age $+\operatorname{lnKFI} \times$ den & 1.2 & 0.307 & 0.55 & 11 \\
\hline $\operatorname{den}($ lo $/$ no, hi $)+$ lact + precip $+\operatorname{lnKFI}+>13+$ age $+\operatorname{lnKFI} \times$ den & 5.3 & 0.039 & 0.07 & 8 \\
\hline $\operatorname{den}($ lo, no, hi $)+$ lact + precip $+\operatorname{lnKFI}+>13+$ age & 6.1 & 0.026 & 0.05 & 8 \\
\hline $\operatorname{den}($ lo $/$ no, hi $)+$ lact + precip $+\operatorname{lnKFI}+>13+$ age & 6.8 & 0.019 & 0.03 & 7 \\
\hline $\operatorname{den}($ lo, no, hi $)+$ lact + precip $+\operatorname{lnKFI}+>13+$ age $+\operatorname{lnKFI} \times \operatorname{den}$ & 7.1 & 0.016 & 0.03 & 10 \\
\hline Intercept & 90.1 & 0.000 & 0.00 & 1 \\
\hline
\end{tabular}

for model validation, but the only empirical measurements of body fat, lactation status, and age for northeast Oregon elk were from management units where the number of archery hunters was comparable to our low archer density. Applying our models to these same data using high archer density resulted in a $7.0 \%$ decrease $(0.915-0.851)$ in pregnancy rate estimates, which would not fully explain the decline in end-of-winter juvenile to female ratios observed in northeast Oregon.

\section{Effects on Behavior and Energetic Costs}

At Starkey, we manipulated archer density in a landscape experiment to evaluate responses of a variety of elk population parameters. Our study was intentionally designed to not allow elk to escape from the designed level of hunting pressure associated with levels of archer density. On some landscapes, this level of hunting pressure may be less uniform, and elk may be able to evade hunting pressure, mitigating predicted effects under our models. However, elk moving away from high hunting pressure would be expected to increase their movement rates and energy expenditures in the process, as well as use environments that might otherwise not be selected (Johnson et al. 2004). Elk moving to similar quality habitat with less hunting pressure would likely have reduced negative effects, but elk moving to poorer quality habitat with less hunting pressure could still incur negative effects (Cook et al. 2004a). Similarly, elk moving to areas of steeper terrain to escape hunting pressure would increase their locomotion costs (Parker et al. 1984).

Additional sources of human disturbance outside hunting seasons also may increase energetic costs to elk or alter their use of greater nutrition habitats, with potentially negative effects on productivity. Mean conception dates for lactating elk during the years of high archer densities was 9 October. In Oregon, the deer rifle season occurs during the first 2 weeks of October, and could result in additive negative effects on conception dates and pregnancy rates. Likewise, elk movement rates can increase substantially in areas of allterrain vehicle riding during spring, summer, and fall before hunting seasons (Wisdom et al. 2004a); elk distributions also shift away from motorized routes (Rowland et al. 2000, Wisdom et al. 2004b).

\section{MANAGEMENT IMPLICATIONS}

In areas where juvenile to female elk ratios are below the maintenance level of 23:100 (Oregon Department of Fish

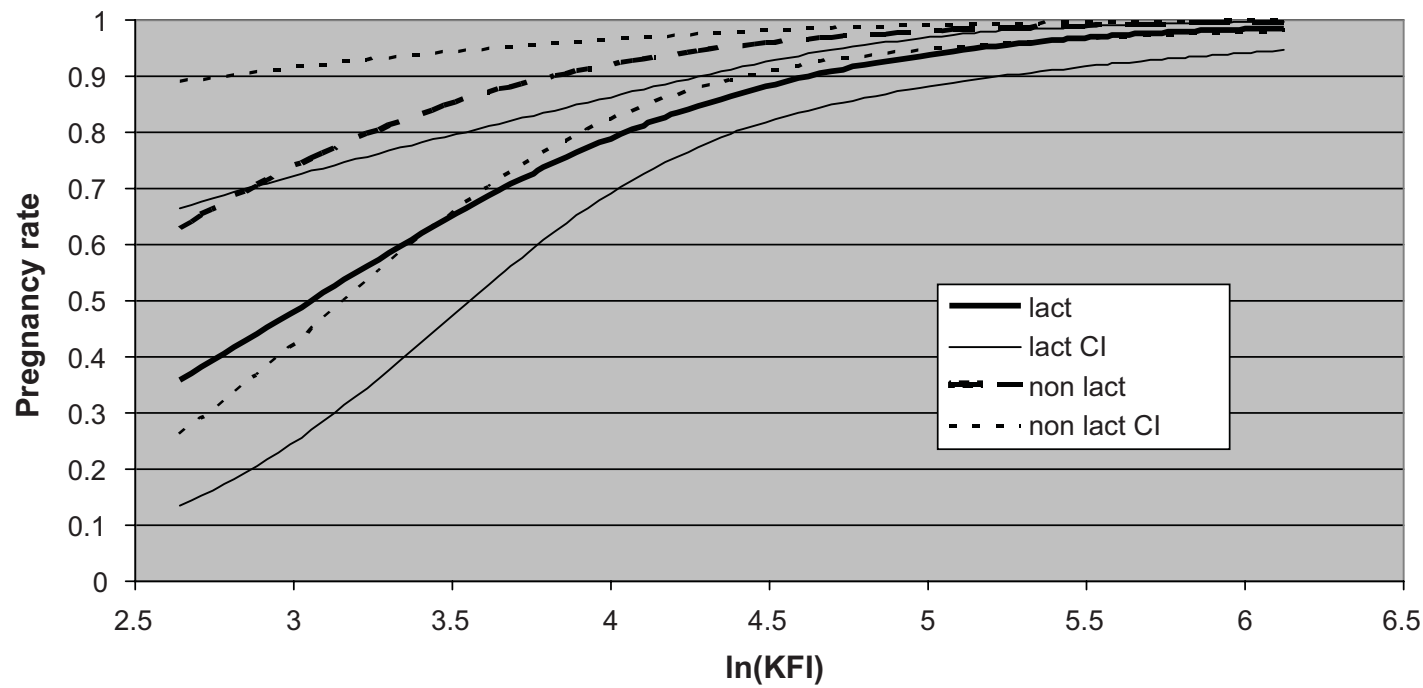

Figure 4. Pregnancy rates and $95 \%$ confidence intervals (CI) across lognormally distributed kidney fat index, $\ln (\mathrm{KFI})$, for lactating (lact), and non-lactating (nonlact) female elk 2- to 21-year old during the years of no archers during the rut at the Starkey Experimental Forest and Range, Oregon, USA, 1991-1993 and 1997-1999. 
and Wildlife 2003), managers should consider effects of archery hunting disturbance during the rut in the design of comprehensive management strategies to increase elk productivity, but realize high archer density alone will not result in low recruitment. Since the effects of high archer densities compared to low archer densities were significantly different, managers would benefit by obtaining accurate estimates of archery hunters. Managers could then identify units of concern that also have high hunter densities, and subsequently adjust archer numbers by limiting licenses. Using an adaptive management strategy, managers could require archers to choose a unit to hunt, which would allow for the flexibility of limiting archer tags in units of concern. Additionally, the cumulative effects of human disturbance during both hunting and non-hunting seasons may be important to consider in meeting management objectives for elk productivity.

\section{ACKNOWLEDGMENTS}

The study was supported by Federal Aid in Wildlife Restoration Grant W-87-R, the Oregon Department of Fish and Wildlife, and the United States Forest Service Pacific Northwest Research Station. We appreciate the efforts of project personnel C. D. Borum, P. K. Coe, S. L. Findholt, R. O. Kennedy, P. B. Kennington, L. Naylor, J. C. Nothwang, A. Stokes, and R. J. Stussy. R. L. Green assisted with laboratory exams of elk reproductive organs, kidney fat measurements, and processing teeth for age determination. We thank J. G. Cook, R. C. Cook, R. M. Nielson, and G. C. White for suggestions during the analysis. Draft manuscripts were reviewed by D. Clark, A. C. Heath, M. T. Kirsch, S. McCorquodale, and 2 anonymous reviewers.

\section{LITERATURE CITED}

Albon, S. D., B. Mitchell, B. J. Huby, and D. Brown. 1986. Fertility in female red deer (Cervus elaphus). The effects of body-composition, age and reproductive status. Journal of Zoology 209:447-460.

Arnold, T. W. 2010. Uninformative parameters and model selection using Akaike's Information Criterion. Journal of Wildlife Management 74:1175-1178.

Burnham, K. P., and D. R. Anderson. 2002. Model selection and multimodel inference: a practical information-theoretic approach. Second edition. Springer-Verlag, New York, New York, USA.

Cameron, R. D., W. T. Smith, S. G. Fancy, K. L. Gerhart, and R. G. White. 1993. Calving success of female caribou in relation to body weight. Canadian Journal of Zoology 71:480-486.

Coe, P. K., B. K. Johnson, M. J. Wisdom, J. G. Cook, M. Vavra, and R. M. Nielson. 2011. Validation of elk resource selection models with spatially independent data. Journal of Wildlife Management 75:159-170.

Conner, M. M., G. C. White, and D. J. Freddy. 2001. Elk movement in response to early-season hunting in northwest Colorado. Journal of Wildlife Management 65:926-940.

Cook, R. C., J. G. Cook, and L. D. Mech. 2004b. Nutritional condition of northern Yellowstone elk. Journal of Mammalogy 85:714-722.

Cook, R. C., J. G. Cook, D. L. Murray, P. Zager, B. K. Johnson, and M. W. Gratson. 2001a. Development of predictive models of nutritional condition for Rocky Mountain elk. Journal of Wildlife Management 65:973987.

Cook, J. G., B. K. Johnson, R. C. Cook, R. A. Riggs, T. Delcurto, L. D. Bryant, and L. L. Irwin. 2004a. Effects of summer-autumn nutrition and parturition date on reproduction and survival of elk. Wildlife Monographs $1-61$.
Cook, R. C., D. L. Murray, J. G. Cook, P. Zager, and S. L. Monfort. $2001 b$. Nutritional influences on breeding dynamics in elk. Canadian Journal of Zoology 79:845-853.

Cook, R. C., T. R. Stephenson, W. L. Myers, J. G. Cook, and L. A. Shipley. 2007. Validating predictive models of nutritional condition for mule deer. Journal of Wildlife Management 71:1934-1943.

Coughenour, M. B., and F. J. Singer. 1996. Elk population processes in Yellowstone National Park under the policy of natural regulation. Ecological Applications 6:573-593.

Davidson, G. A. 2007. Analyzing elk movements and distributions in Colorado using generalized linear models. Thesis, Colorado State University, Ft. Collins, USA.

Garrott, R. A., L. L. Eberhardt, P. J. White, and J. Rotella. 2003. Climateinduced variation in vital rates of an unharvested large-herbivore population. Canadian Journal of Zoology-Revue Canadienne De Zoologie 81:33-45.

Gerhart, K. L., D. E. Russell, D. VanDewetering, R. G. White, and R. D. Cameron. 1997. Pregnancy of adult caribou (Rangifer tarandus): evidence for lactational infertility. Journal of Zoology 242:17-30.

Hines, W. W., and J. C. Lemos. 1979. Reproductive performance by two age-classes of male Roosevelt elk in southwestern Oregon. Oregon Department of Fish and Wildlife, Wildlife Research Report 8, Portland, USA.

I'Anson, H., D. L. Foster, G. R. Foxcroft, and P. J. Booth. 1991. Nutrion and reproduction. Oxford Reviews of Reproductive Biology 13:239311.

Johnson, B. K., A. A. Ager, J. H. Noyes, and N. Cimon. 2004. Elk and mule deer responses to variation in hunting pressure. Transactions of the 69th North American Wildlife and Natural Resources Conference: 625640 .

Kohlmann, S. G. 1999. Adaptive fetal sex allocation in elk: evidence and implications. Journal of Wildlife Management 63:1109-1117.

Loison, A., and R. Lagvatn. 1998. Short- and long-term effects of winter and spring weather on growth and survival of red deer in Norway. Oecologia 116:489-500.

Martin, G. B., J. T. B. Milton, R. H. Davidson, G. E. B. Hunzicker, D. R. Lindsay, and D. Blache. 2004. Natural methods for increasing reproductive efficiency in small ruminants. Animal Reproduction Science 8283:231-246.

Mitchell, B., and G. A. Lincoln. 1973. Conception dates in relation to age and condition in 2 populations of red deer in Scotland. Journal of Zoology 171:141-152.

Molle, G., A. Branca, S. Ligios, M. Sitzia, S. Casu, S. Landau, and Z. Zoref. 1995. Effect of grazing background and flushing suplemntation on reproductive performance in Sarda erwes. Small Ruminant Research 17:245254.

National Research Council. 1985. Nutrient requirements of sheep. Sixth edition. National Academy of Science, Washington, D.C., USA.

Noyes, J. H., B. K. Johnson, L. D. Bryant, S. L. Findholt, and J. W. Thomas. 1996. Effects of bull age on conception dates and pregnancy rates of cow elk. Journal of Wildlife Management 60:508-517.

Noyes, J. H., B. K. Johnson, B. L. Dick, and J. G. Kie. 2002. Effects of male age and female nutritional condition on elk reproduction. Journal of Wildlife Management 66:1301-1307.

Oregon Department of Fish and Wildlife. 1992. Oregon's elk management plan. Oregon Department of Fish and Wildlife, Salem, USA.

Oregon Department of Fish and Wildlife. 2003. Big game statistics. Oregon Department of Fish and Wildlife, Salem, USA.

Oregon Department of Fish and Wildlife. 2010. Big game statistics. Oregon Department of Fish and Wildlife, Salem, USA.

Parker, K. L., C. T. Robbins, and T. A. Hanley. 1984. Energy expenditures for locomotion by mule deer and elk. Journal of Wildlife Management 48:474-488.

PRISM Climate Group. 2010. Latest PRISM data. <http://www.prism. oregonstate.edu $>$. Accessed 5 Dec 2011.

Rearden, S. N. 2005. Juvenile survival and birth-site selection of Rocky Mountain elk in northeastern Oregon. Thesis, Oregon State University, Corvallis, USA.

Rowland, M. M., L. D. Bryant, B. K. Johnson, J. H. Noyes, M. J. Wisdom, and J. W. Thomas. 1997. The Starkey project: history, facilities, and data collection methods for ungulate research. U.S. Department of Agriculture, 
Forest Service, Pacific Northwest Research, Station. General Technical Report PNW-GTR-396. Portland, Oregon, USA.

Rowland, M. M., M. J. Wisdom, B. K. Johnson, and J. G. Kie. 2000. Elk distribution and modeling in relation to roads. Journal of Wildlife Management 64:672-684.

Schenker, N., and J. F. Gentleman. 2001. On judging the significance of differences by examining the overlap between confidence intervals. American Statistician 55:182-186.

Schwartz, C. C., and K. J. Hundertmark. 1993. Reproductive characteristics of Alaskan moose. Journal of Wildlife Management 57:454-468.

Skogland, T. 1983. The effects of density dependent resource limitation on size of wild reindeer. Oecologia 60:156-168.

Squibb, R. C., J. F. Kimball, Jr., and D. R. Anderson. 1986. Bimodal distribution of estimated conception dates in Rocky Mountain elk. Journal of Wildlife Management 50:118-122.

Squibb, R. C. 1985. Mating success of yearling and older bull elk. Journal of Wildlife Management 49:744-750.

Trainer, C. E. 1971. The relationship of physical condition and fertility of female Roosevelt elk (Cervus canadensis roosevelti) in Oregon. Thesis, Oregon State University, Corvallis, USA.

Unsworth, J. W., F. A. Leban, D. J. Leptich, E. O. Garton, and P. Zager. 1994. Aerial survey: user's manual. Second edition. Idaho Department of Fish and Game, Boise, USA.

Verme, L. J. 1965. Reproductive studies on penned white-tailed deer. Journal of Wildlife Management 29:74-79.
Vieira, M. E. P., M. M. Conner, G. C. White, and D. J. Freddy. 2003. Effects of archery hunter numbers and opening dates on elk movement. Journal of Wildlife Management 67:717-728.

Washington Department of Fish and Wildlife. 2009. 2009 Game status and trend report. Wildlife Program. Washington Department of Fish and Wildlife, Olympia, USA.

White, C. G., P. Zager, and M. W. Gratson. 2010. Influence of predator harvest, biological factors, and landscape on elk calf survival in Idaho. Journal of Wildlife Management 74:355-369.

Wisdom, M. J., A. A. Ager, H. K. Preisler, N. J. Cimon, and B. K. Johnson. 2004a. Effects of off-road recreation on mule deer and elk. Transactions of the 69th North American Wildlife and Natural Resources Conference: 531-550.

Wisdom, M. J., N. J. Cimon, B. K. Johnson, E. O. Garton, and J. W. Thomas. 2004b. Spatial partitioning by mule deer and elk in relation to traffic. Transactions of the 69th North American Wildlife and Natural Resources Conference, Alliance Communications Group. 509530.

Wisdom, M. J., J. G. Cook, M. M. Rowland, and J. H. Noyes. 1993. Protocols for care and handling of deer and elk at the Starkey Experimental Forest and Range. USDA Forest Service Pacific Northwest Research Station PNW-GTR-311, Portland, Oregon, USA.

Associate Editor: Scott McCorquodale. 
Appendix 1. A priori models for logistic regression applied to pregnancy rates of female elk 2-21 years old at the Starkey

Experimental Forest and Range, Oregon, 1991-1993 and 1997-2006 using Akiake's Information Criteria for small sample sizes $\left(\mathrm{AIC}_{c}\right) \cdot \operatorname{lnKFI}=\ln ($ kidney fat index $)$, lact $=$ lactation status, precip $=15 \mathrm{July}-15$ October precipitation, $>13=$ binomial variable for elk $>13$ years old, den = mean daily archer density, hi = high archer density group, lo = low archer density group, no = no archer density group, hi/lo = pooled high and low archer density groups, and low/no = pooled low and no archer density groups. Difference between $\mathrm{AIC}_{c}$ and that of the top model $\left(\Delta \mathrm{AIC}_{c}\right)$, Akaike's weight $\left(w_{i}\right)$, log-likelihood $(\mathrm{LL})$, and number of parameters $(K)$ are reported.

\begin{tabular}{|c|c|c|c|c|}
\hline Model & $\Delta \mathrm{AIC}_{c}$ & $w_{i}$ & LL & $K$ \\
\hline $\operatorname{den}($ lo/no, hi $)+$ lact + precip $+\operatorname{lnKFI}+>13+$ age $+\operatorname{lnKFI} \times$ den & 0.0 & 0.184 & 1.000 & 8 \\
\hline $\operatorname{den}($ lo/no, hi $)+$ lact + precip $+\operatorname{lnKFI}+>13+\operatorname{lnKFI} \times d e n$ & 0.5 & 0.144 & 0.782 & 7 \\
\hline $\operatorname{den}($ lo/no, hi $)+$ lact + precip $+\operatorname{lnKFI}+>13+$ age & 0.7 & 0.127 & 0.692 & 7 \\
\hline $\operatorname{den}($ lo/no, hi $)+$ lact + precip $+\operatorname{lnKFI}+>13$ & 1.2 & 0.099 & 0.537 & 6 \\
\hline $\operatorname{den}($ lo, no, hi $)+$ lact + precip $+\operatorname{lnKFI}+>13+$ age & 1.6 & 0.081 & 0.443 & 8 \\
\hline $\operatorname{den}(l o$, no, hi $)+$ lact + precip $+\operatorname{lnKFI}+>13+$ age $+\operatorname{lnKFI} \times d e n$ & 2.3 & 0.059 & 0.320 & 10 \\
\hline $\operatorname{den}(\mathrm{lo}$, no, hi $)+$ lact + precip $+\operatorname{lnKFI}+>13+\operatorname{lnKFI} \times d e n$ & 2.4 & 0.054 & 0.295 & 9 \\
\hline $\operatorname{den}($ lo, no, hi $)+$ lact + precip $+\operatorname{lnKFI}+>13$ & 2.5 & 0.052 & 0.285 & 7 \\
\hline $\operatorname{den}($ lo/no, hi $)+$ lact + precip $+\operatorname{lnKFI}$ & 2.7 & 0.047 & 0.255 & 5 \\
\hline
\end{tabular}




\begin{tabular}{|c|c|c|c|}
\hline $\operatorname{den}(l o$, no, hi $)+$ lact $+\operatorname{lnKFI}+$ precip & 3.7 & 0.029 & 0.156 \\
\hline den $($ lo/no, hi $)+$ lact + precip $+\operatorname{lnKFI}+$ age $+\operatorname{lnKFI} \times$ den & 4.1 & 0.024 & 0.129 \\
\hline lact + precip $+\operatorname{lnKFI}+>13$ & 5.5 & 0.012 & 0.063 \\
\hline lact + precip $+\operatorname{lnKFI}+>13+$ age & 5.7 & 0.011 & 0.059 \\
\hline $\operatorname{den}($ hi/lo, no $)+$ lact + precip $+\operatorname{lnKFI}+>13+\operatorname{lnKFI} \times$ den & 5.8 & 0.010 & 0.055 \\
\hline den $(l o$, no, hi $)+$ lact + precip $+\operatorname{lnKFI}+$ age $+\operatorname{lnKFI} \times d e n$ & 6.1 & 0.009 & 0.047 \\
\hline lact $+\operatorname{lnKFI}+$ precip & 6.6 & 0.007 & 0.038 \\
\hline $\operatorname{den}($ hi $/ l o$, no $)+$ lact + precip $+\operatorname{lnKFI}+>13$ & 6.6 & 0.007 & 0.037 \\
\hline $\operatorname{den}(\mathrm{hi} / \mathrm{lo}$, no $)+$ lact + precip $+\operatorname{lnKFI}+>13+$ age $+\operatorname{lnKFI} \times d e n$ & 6.6 & 0.007 & 0.036 \\
\hline $\operatorname{den}($ hi $/$ lo, no $)+$ lact + precip $+\operatorname{lnKFI}+>13+$ age & 6.8 & 0.006 & 0.034 \\
\hline $\operatorname{den}($ hi/lo, no $)+$ lact $+\operatorname{lnKFI}+$ precip & 7.9 & 0.004 & 0.019 \\
\hline $\operatorname{den}($ lo/no, hi $)+$ lact $+\operatorname{lnKFI}+>13$ & 7.9 & 0.003 & 0.019 \\
\hline $\operatorname{den}(\mathrm{lo} / \mathrm{no}, \mathrm{hi})+\mathrm{lact}+\operatorname{lnKFI}+>13+\operatorname{lnKFI} \times \mathrm{den}$ & 8.1 & 0.003 & 0.018 \\
\hline $\operatorname{den}(\mathrm{lo} / \mathrm{no}, \mathrm{hi})+$ lact $+\operatorname{lnKFI}+>13+$ age & 8.3 & 0.003 & 0.016 \\
\hline $\operatorname{den}($ lo/no, hi $)+$ lact $+\operatorname{lnKFI}+>13+$ age $+\operatorname{lnKFI} \times$ den & 8.5 & 0.003 & 0.014 \\
\hline lact + precip $+\ln K F I+$ age & 8.5 & 0.003 & 0.014 \\
\hline
\end{tabular}




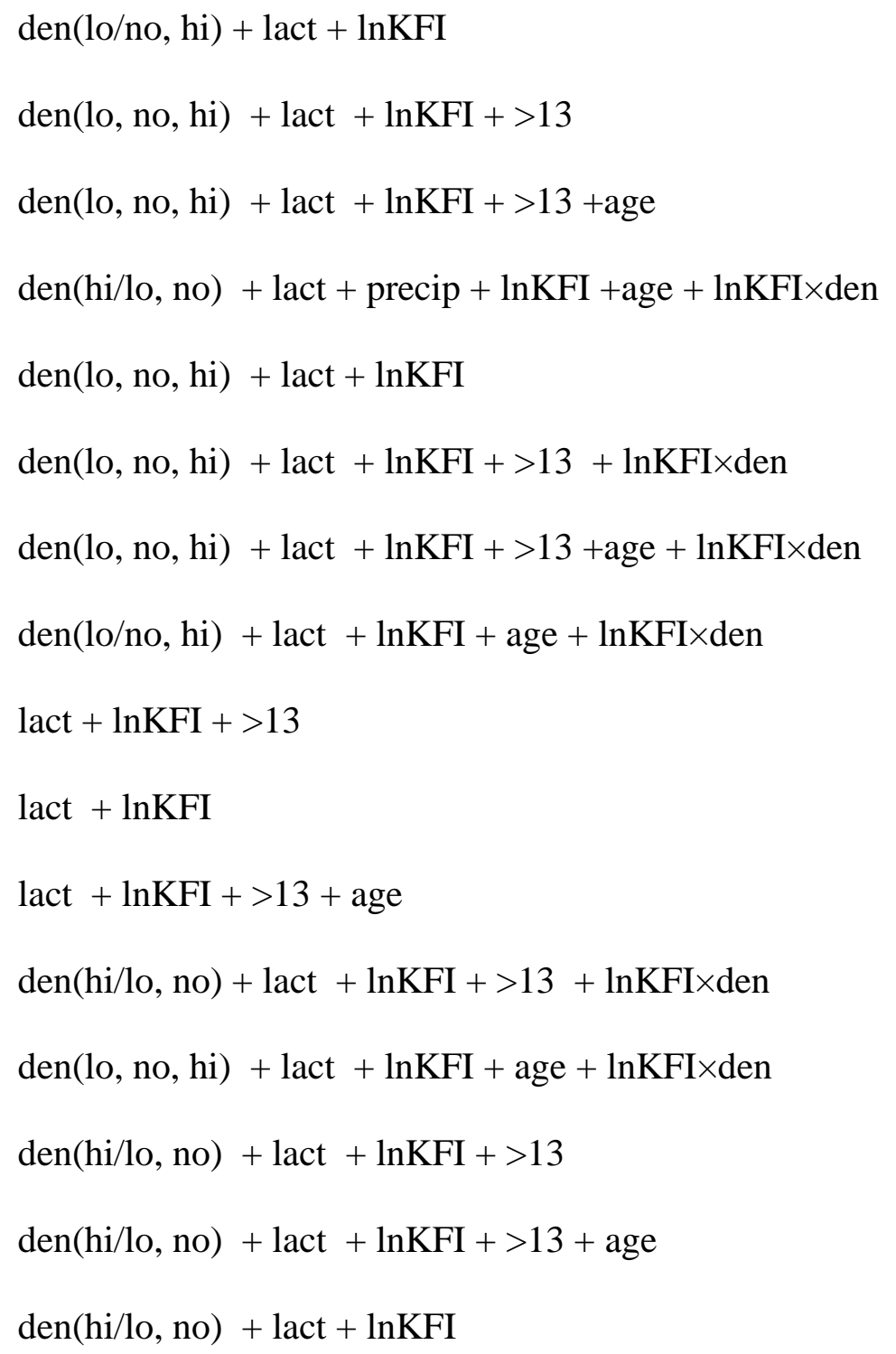

\begin{tabular}{|c|c|c|}
\hline 8.8 & 0.002 & 0.013 \\
\hline 9.2 & 0.002 & 0.010 \\
\hline 9.3 & 0.002 & 0.009 \\
\hline 9.3 & 0.002 & 0.009 \\
\hline 9.7 & 0.001 & 0.008 \\
\hline 9.9 & 0.001 & 0.007 \\
\hline 10.7 & 0.001 & 0.005 \\
\hline 10.9 & 0.001 & 0.004 \\
\hline 11.7 & 0.001 & 0.003 \\
\hline 12.3 & 0.000 & 0.002 \\
\hline 12.4 & 0.000 & 0.002 \\
\hline 12.6 & 0.000 & 0.002 \\
\hline 12.7 & 0.000 & 0.002 \\
\hline 13.0 & 0.000 & 0.002 \\
\hline 13.8 & 0.000 & 0.001 \\
\hline 13.8 & 0.000 & 0.001 \\
\hline
\end{tabular}




\begin{tabular}{|c|c|c|c|}
\hline $\operatorname{den}($ hi/lo, no $)+$ lact $+\operatorname{lnKFI}+>13+$ age $+\operatorname{lnKFI} \times$ den & 13.9 & 0.000 & 0.001 \\
\hline lact $+\operatorname{lnKFI}+$ age & 14.2 & 0.000 & 0.001 \\
\hline $\operatorname{den}($ hi/lo, no $)+$ lact $+\operatorname{lnKFI}+$ age + lnKFI $\times$ den & 15.4 & 0.000 & 0.000 \\
\hline Intercept & 84.5 & 0.000 & 0.000 \\
\hline Trend & 84.5 & 0.000 & 0.000 \\
\hline Year & 85.1 & 0.000 & 0.000 \\
\hline
\end{tabular}


1 Appendix 2. A priori models for generalized linear models regression applied to conception dates of female elk 2-21 years old at the

2 Starkey Experimental Forest and Range, Oregon, 1991-1993 and 1997-2006 using Akiake's Information Criteria adjusted for small

3 sample sizes $\left(\mathrm{AIC}_{c}\right) \cdot \operatorname{lnKFI}=\ln ($ kidney fat index $)$, lact $=$ lactation status, precip $=15 \mathrm{July}-15$ October precipitation, $>13=$ binomial

4 variable for elk $>13$ years old, male:female $=$ number of males $>3$ years per 100 females $>2$ years, den $=$ mean daily archer density, hi

5 = high archer density group, lo = low archer density group, no = no archer density group, hi/lo = pooled high and low archer density

6 groups, and low/no = pooled low and no archer density groups. Difference between $\mathrm{AIC}_{c}$ and that of the top model $(\Delta \mathrm{AIC} c), \mathrm{Akaike}{ }_{\mathrm{s}}$

7 weight $\left(w_{i}\right)$, log-likelihood (LL), and number of parameters $(K)$ are reported.

\begin{tabular}{|c|c|c|c|c|c|}
\hline Model & $\mathrm{AIC}_{c}$ & $\Delta \mathrm{AIC}_{c}$ & $w_{i}$ & LL & $K$ \\
\hline den $($ lo, no, hi $)+$ lact + precip + male:female $+\operatorname{lnKFI}+>13+$ age & -1955.8 & 0.0 & 0.553 & 1.00 & 9 \\
\hline $\operatorname{den}($ lo, no, hi $)+$ lact + precip + male:female $+\operatorname{lnKFI}+>13+$ age $+\operatorname{lnKFI} \times d e n$ & -1954.6 & 1.2 & 0.307 & 0.55 & 11 \\
\hline $\operatorname{den}($ lo/no, hi $)+$ lact + precip $+\operatorname{lnKFI}+>13+$ age $+\operatorname{lnKFI} \times$ den & -1950.5 & 5.3 & 0.039 & 0.07 & 8 \\
\hline $\operatorname{den}(l o$, no, hi $)+$ lact + precip $+\operatorname{lnKFI}+>13+$ age & -1949.7 & 6.1 & 0.026 & 0.05 & 8 \\
\hline $\operatorname{den}(\mathrm{lo} / \mathrm{no}, \mathrm{hi})+$ lact + precip $+\operatorname{lnKFI}+>13+$ age & -1949.0 & 6.8 & 0.019 & 0.03 & 7 \\
\hline $\operatorname{den}(l o$, no, hi $)+$ lact + precip $+\operatorname{lnKFI}+>13+$ age $+\operatorname{lnKFI} \times d e n$ & -1948.7 & 7.1 & 0.016 & 0.03 & 10 \\
\hline $\operatorname{den}(\mathrm{lo} / \mathrm{no}, \mathrm{hi})+$ lact + precip + male:female $+\operatorname{lnKFI}+>13+$ age $+\operatorname{lnKFI} \times$ den & -1948.4 & 7.4 & 0.014 & 0.03 & 9 \\
\hline den $($ lo/no, hi $)+$ lact + precip + male:female $+\operatorname{lnKFI}+>13+$ age & -1946.9 & 8.9 & 0.007 & 0.01 & 8 \\
\hline $\operatorname{den}($ lo, no, hi $)+$ lact $+\ln K F I+>13+$ age & -1946.8 & 9.0 & 0.006 & 0.01 & 7 \\
\hline
\end{tabular}




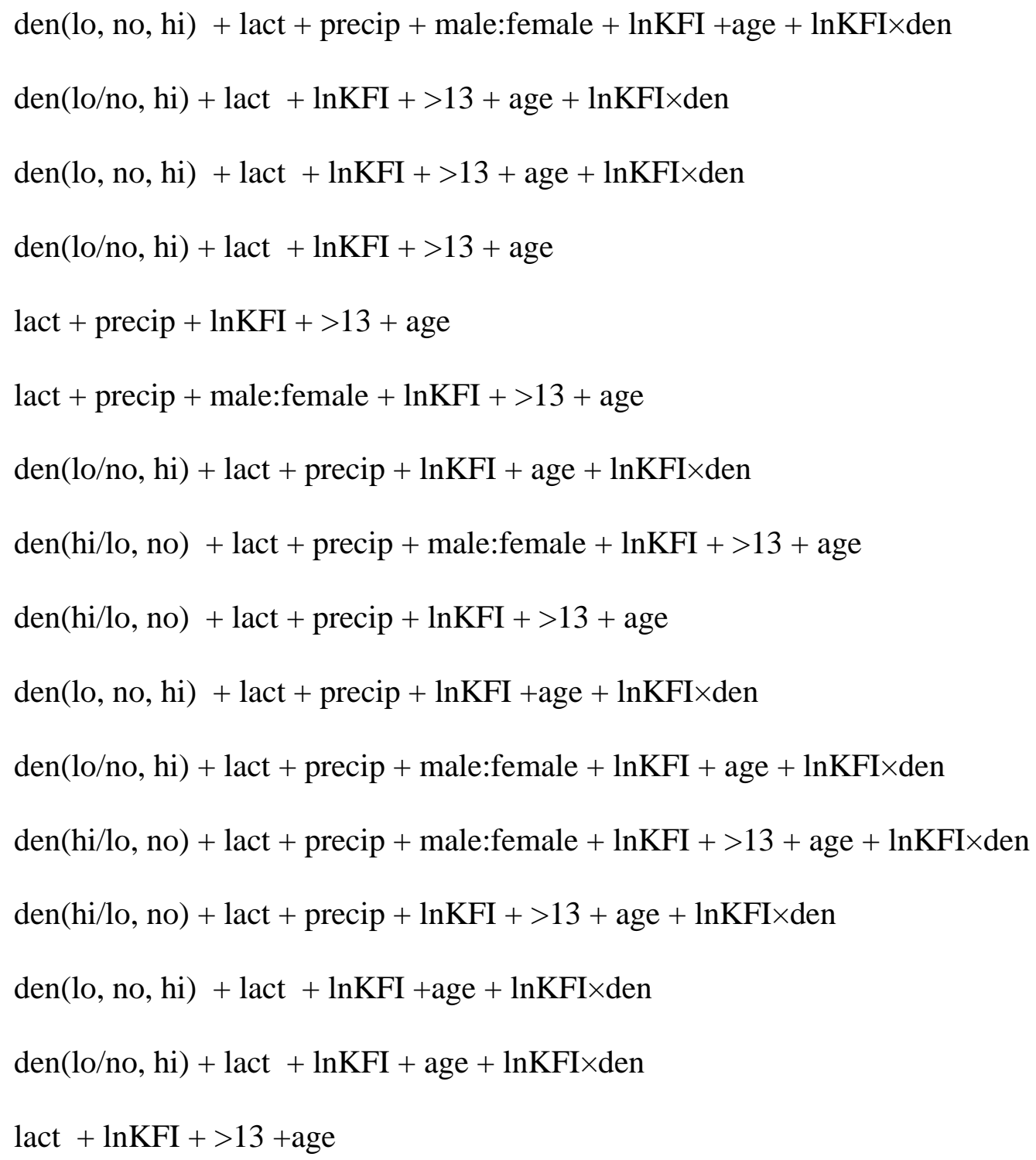

$\begin{array}{lllll}-1945.5 & 10.3 & 0.003 & 0.01 & 10 \\ -1945.4 & 10.5 & 0.003 & 0.01 & 7 \\ -1944.9 & 10.9 & 0.002 & 0.00 & 9 \\ -1944.6 & 11.3 & 0.002 & 0.00 & 6 \\ -1942.7 & 13.1 & 0.001 & 0.00 & 6 \\ -1941.9 & 13.9 & 0.001 & 0.00 & 7 \\ -1941.9 & 13.9 & 0.001 & 0.00 & 7 \\ -1941.0 & 14.8 & 0.000 & 0.00 & 8 \\ -1940.9 & 14.9 & 0.000 & 0.00 & 7 \\ -1940.7 & 15.1 & 0.000 & 0.00 & 9 \\ -1939.8 & 16.0 & 0.000 & 0.00 & 8 \\ -1939.1 & 16.7 & 0.000 & 0.00 & 9 \\ -1939.0 & 16.9 & 0.000 & 0.00 & 8 \\ -1938.0 & 17.8 & 0.000 & 0.00 & 8 \\ -1937.7 & 18.1 & 0.000 & 0.00 & 6 \\ -1935.5 & 20.3 & 0.000 & 0.00 & 5\end{array}$




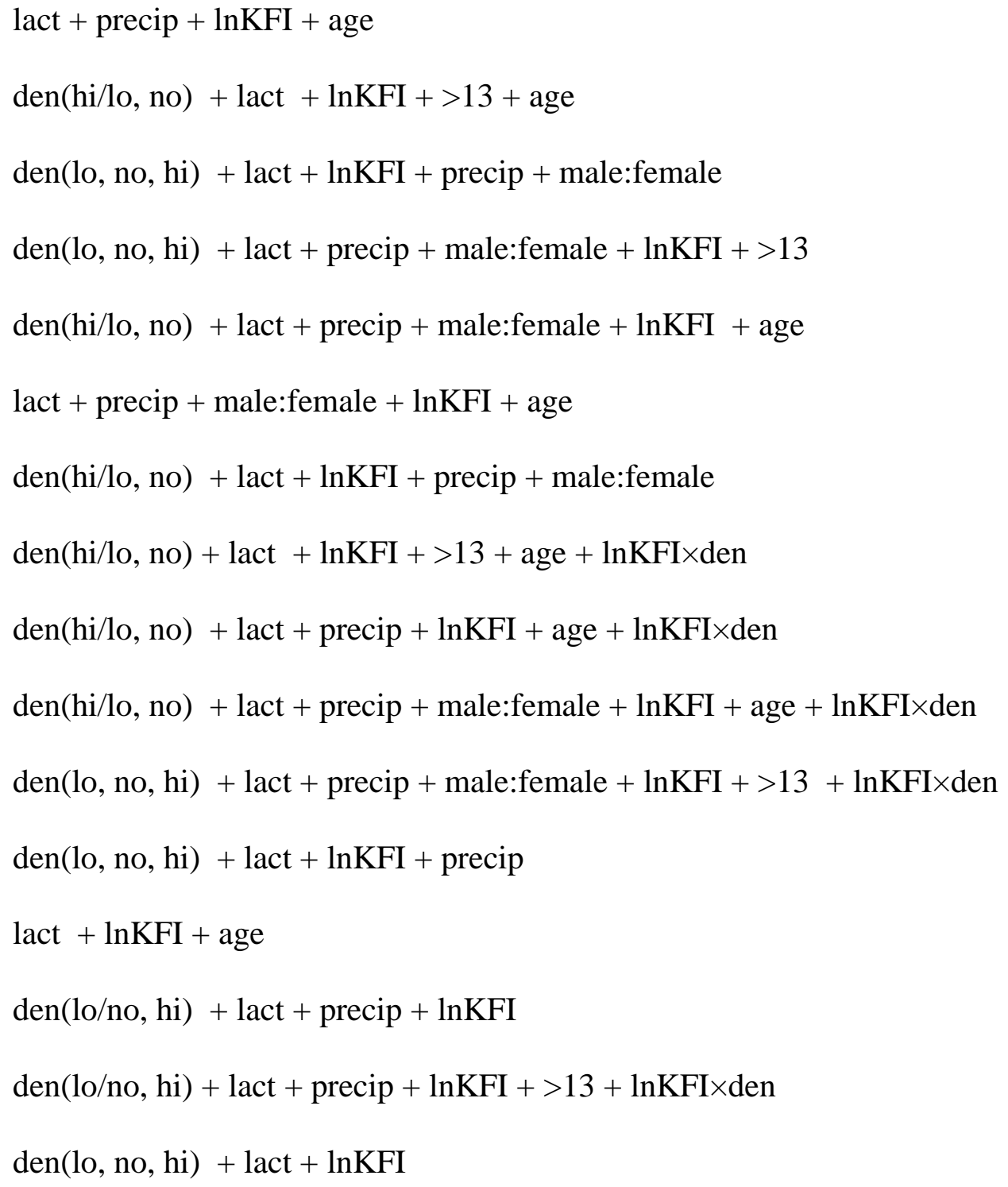

\begin{tabular}{|c|c|c|c|}
\hline-1934.7 & 21.1 & 0.000 & 0.00 \\
\hline-1933.5 & 22.3 & 0.000 & 0.00 \\
\hline-1933.4 & 22.4 & 0.000 & 0.00 \\
\hline-1933.4 & 22.4 & 0.000 & 0.00 \\
\hline-1933.2 & 22.6 & 0.000 & 0.00 \\
\hline-1933.2 & 22.6 & 0.000 & 0.00 \\
\hline-1933.2 & 22.6 & 0.000 & 0.00 \\
\hline-1931.6 & 24.2 & 0.000 & 0.00 \\
\hline-1931.0 & 24.8 & 0.000 & 0.00 \\
\hline-1930.6 & 25.2 & 0.000 & 0.00 \\
\hline-1930.6 & 25.3 & 0.000 & 0.00 \\
\hline-1928.9 & 26.9 & 0.000 & 0.00 \\
\hline-1928.7 & 27.1 & 0.000 & 0.00 \\
\hline-1928.0 & 27.8 & 0.000 & 0.00 \\
\hline-1927.9 & 27.9 & 0.000 & 0.00 \\
\hline-1927.9 & 27.9 & 0.000 & 0.00 \\
\hline
\end{tabular}




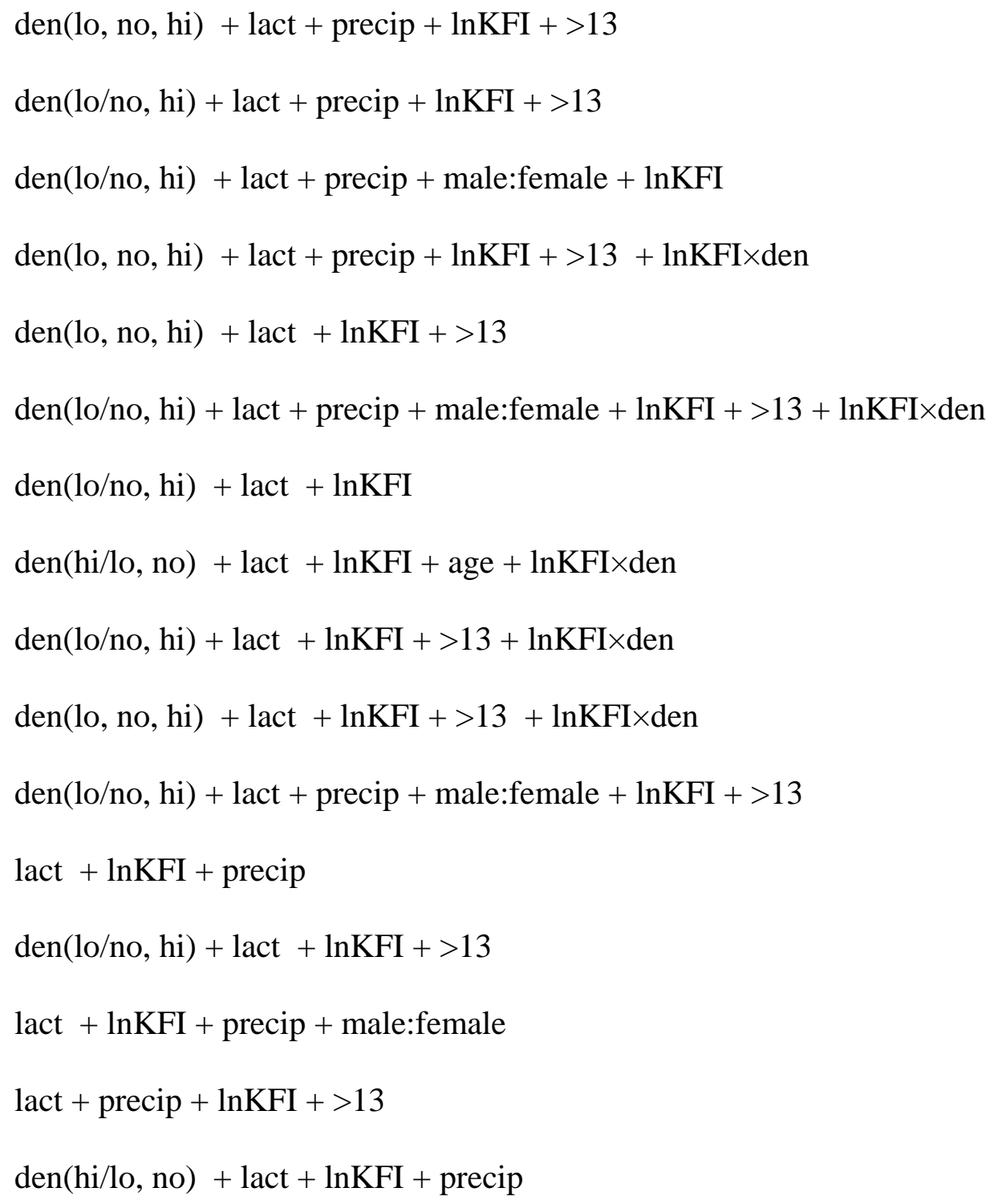

$\begin{array}{lllll}-1926.0 & 29.8 & 0.000 & 0.00 & 6 \\ -1925.9 & 29.9 & 0.000 & 0.00 & 9 \\ -1925.8 & 30.0 & 0.000 & 0.00 & 6 \\ -1925.8 & 30.0 & 0.000 & 0.00 & 8 \\ -1925.7 & 30.1 & 0.000 & 0.00 & 6 \\ -1925.0 & 30.8 & 0.000 & 0.00 & 6 \\ -1924.9 & 30.9 & 0.000 & 0.00 & 6 \\ -1924.4 & 31.4 & 0.000 & 0.00 & 8 \\ -1924.0 & 31.8 & 0.000 & 0.00 & 7 \\ -1924.0 & 31.8 & 0.000 & 0.00 & 4 \\ -1923.7 & 32.1 & 0.000 & 0.00 & 5 \\ -1922.5 & 33.3 & 0.000 & 0.00 & 5 \\ -1922.0 & 33.8 & 0.000 & 0.00 & 5 \\ -1922.0 & 33.8 & 0.000 & 0.00 & 5\end{array}$




\begin{tabular}{|c|c|c|c|c|c|}
\hline lact + precip + male:female $+\operatorname{lnKFI}+>13$ & -1920.6 & 35.2 & 0.000 & 0.00 & 6 \\
\hline lact $+\operatorname{lnKFI}$ & -1919.5 & 36.3 & 0.000 & 0.00 & 3 \\
\hline $\operatorname{den}($ hi/lo, no $)+$ lact + precip + male:female $+\operatorname{lnKFI}+>13+\operatorname{lnKFI} \times$ den & -1918.7 & 37.2 & 0.000 & 0.00 & 8 \\
\hline lact $+\operatorname{lnKFI}+>13$ & -1917.6 & 38.2 & 0.000 & 0.00 & 4 \\
\hline $\operatorname{den}($ hi/lo, no $)+$ lact + lnKFI & -1917.5 & 38.3 & 0.000 & 0.00 & 4 \\
\hline Year & -1888.1 & 67.7 & 0.000 & 0.00 & 13 \\
\hline Intercept & -1865.7 & 90.1 & 0.000 & 0.00 & 1 \\
\hline Trend & -1865.3 & 90.5 & 0.000 & 0.00 & 2 \\
\hline
\end{tabular}

